\title{
The Similarity of Indonesian and British Women's Views on Marriage in the Novels Alisjahbana's Layar Terkembang and Austen's Pride And Prejudice
}

\begin{abstract}
Abbas Abbas
Cultural sciences Faculty, Hasanuddin University

Email:abbas@unhas.ac.id

ABSTRACT

This article discusses the views of women related to marriage and household from two different nations, namely Indonesia and Britain. Tuti is an Indonesian woman in the novel Layar Terkembang by Sutan Takdir Alisjahbana and Elizabeth Bennet is a typical British woman in the novel Pride and Prejudice by Jane Austen. The writer in this article emphasizes the similarity of two fictional characters' views between Tuti and Elizabeth about marriage and household. The data of this study were collected from the novel Layar Terkembang and Pride and Prejudice. The structuralism approach is used in processing data that emphasizes the intrinsic aspects of literature, including characterizations. Data that has been processed then analyzed through feminist literary criticism and explained descriptively which describe the results of characterization analysis in the two kinds of literature. Based on the results of the analysis, it is concluded that the similarity of Tuti and Elizabeth's views of marriage are women should not deny marriage as part of the journey of life, married by women should be based on common sense, not because of feelings; women are married because of consciousness not because of men's appeal. Then, the similarity of their views of marriage are women should be given the freedom to empower themselves so they do not always rely on her husband and ignore them, women should be placed as male partners in households, not as rivals or slaves, wife-husband should love each other and seek to live together with realizing hope.
\end{abstract}

Keywords: marriage, household, novel Layar Terkembang, novel Pride and Prejudice.

\section{INTRODUCTION}

Human civilization always produces social and cultural values that document the reality, ideals, views, and hopes of a community or nation. Literature is one product of a human civilization that is honest in documenting the reality, ideals, views, and expectations of certain people. Literary works are sometimes not considered to be of high value at a time when an author published them; especially the language of literature takes a long time to be able to interpret the message hidden in it. Decades or even hundreds of years after literary works were written, readers or researchers sometimes only discover the meaning of the message put forward by fictional characters, including women's views on marriage.

Male superiority and inferiority of women in the household and family are always in the spotlight in some literary stories. The idealization of the aims and hopes of women in marriage, family, and household, comes along with the growing social and intellectual awareness of women. Tuti with her intellectual awareness voiced the idealist views of Indonesian women in the early $20^{\text {th }}$ century in the novel Layar Terkembang by Sutan Takdir Alisjahbana. Likewise, Elizabeth through her social awareness expressed the attitude of British women in the early $19^{\text {th }}$ century in the novel Pride and Prejudice by Jane Austen [9] . According to Fromm [1], the emancipation of women arises because of intellectual, social, and political awareness. This statement indicates that educated women are pioneers in the rise of women in recognizing their obligations as well as fighting for their rights, as Emily Esfahani Smith [2] views in her writing entitled The Power of Meaning: Crafting a Life That Matters.

Smith argues that the relationship between men and women in the household can be harmonious because of the goodness and benefits of marriage. Generally, marriages that fail have an impact on life difficulties, suffering, and dysfunction. This impact is 
not only experienced by married couples, but also by children and families. This broad impact makes educated women consider many aspects before deciding to marry and have a household. Women who are married need physical and psychological readiness.

The early $20^{\text {th }}$ century of the Indonesian nation was a new era for the emergence of educated women who voiced the ideal of the public and domestic world for women. Tuti in the novel Layar Terkembang is a typical educated woman who is full of enthusiasm, ideas, and idealistic views. On the other hand, Great Britain is a nation while enjoying the Industrial Revolution in the early $19^{\text {th }}$ century, which gave rise to women's social problems about marriage which were well resolved by Elizabeth in the novel Pride and Prejudice. Although Tuti and Elizabeth were present at different times of the two different nations, they shared the same views about the position of women in marriage. I, as an English literature academic with an Indonesian background, describes the similarities between the two women's views from these two different nations with the title of the article is The Similarity Of Indonesian And British Women's Views On Marriage In The Novel Alisjahbana's Layar Terkembang and Austen's Pride and Prejudice.

\section{METHODOLOGY}

Literary works are considered to have structures that build stories, including characterizations, plots, settings, and themes. This structure is called the intrinsic elements that determine the existence of the work. Characterization in literary works is a very important element because its presence carries a certain mission that directs the reader to certain issues, such as the presence of Tuti in the novel Layar Terkembang by Sutan Takdir Alisjahbana and Elizabeth in the novel Pride and Prejudice by Jane Austen. Both of these fictional characters carry a mission related to women's views on marriage in the emergence of intellectual and social awareness among women in improving the social order of society which is more inclined to patriarchal culture. Chen [3] explain the presence of female fictional characters in voicing the aspirations of women in the midst of male domination through statements, expressions, and behaviors

The writer describes the views of Indonesian and English women in literary works through the fictional characters of Tuti and Elizabeth so that this analysis uses the theories and methods of feminist literary criticism. This critique emphasizes literary analysis on the position of women in society, looks an imbalance in relations with men, placing men in superior positions and women in inferior positions. Literature readers and researchers trace the position of women in events, treatments, and ideas of female leaders in literary stories. The ideas put forward by the characters of fiction can be interpreted as a form of aspirations and hopes of women in obtaining justice during community social interaction. Wiyatmi [4] expressed her opinion about feminist literary criticism which focused more on gender relations that needed justice to the condition of women in literary works. She stated that feminist literary criticism is one part of a variety of literary criticism that is based on feminism thinking on the achievement of justice in viewing the existence of women, both as authors and in literary works. The focus of the analysis on literary criticism emphasizes the study of women authors, descriptions of women in literary works, the relationship among women and men also society. Feminist literary criticism requires interdisciplinary in exploring the perspective of gender equality and justice.

Literary researchers according to Abbas [5] on the application of feminist literary criticism must focus on the goals of life, behavior, and the establishment of female characters, which are associated with social relations with men. The natural character of female in literature must be traced and recognized, both physically and instinctively, to find an issue in the aspect of social life of the community which is considered as injustice, including inequality of the position of women from men in marriage. Despite the diverse views of the characters in fiction, what is important in the critique of feminist literature is examining the awareness of female characters in addressing women's inferiority in the social life of society as termed by Guerin, et al [6], "the feminine consciousness".

Women's awareness arises because of male domination in the social life of the people published by social media, including literary works. So, the characters in the literature are reflections of feminist issues in certain societies. It is in line with the thinking of Sugihastuti and Itsna Hadi Saptiawan [7] who suggest that feminist literary criticism arises because of the awareness of women about the imbalance of social and cultural structures in the tradition of society. These inequalities are documented in literary stories, then criticized by fictional characters as part of the view of society as done by Tuti, an Indonesian woman and Elizabeth, a British woman in a novel.

Based on the theoretical foundation that has been stated, the writer carries out the steps of the research of this article with the method of feminist literary criticism. The writer begins by thoroughly reading the novel Layar Terkembang by Sutan Takdir Alisjahbana and the novel Pride and Prejudice by Jane Austen. The next step is to study the events in the novel that create certain issues, then explore the behavior, thoughts, and ideals of female characters in fiction. Furthermore, the social relations of female characters with male characters are interpreted as an imbalance of social and cultural structures in the traditions of society. The writer then 
maps the views of Tuti and Elizabeth, then analyzes the similarities in attitudes and views of the two fictional characters about marriage and domestic life.

\section{ANALYSIS}

The writer divides the five sections in discussing and analyzing the novel Layar Terkembang by Sutan Takdir Alisjahbana and the novel Pride and Prejudice by Jane Austen, namely the description of the story of these novels, the view of Tuti in the novel Layar Terkembang, the view of Elizabeth in the novel Pride and Prejudice, the views equality of Tuti and Elizabeth on marriage.

\subsection{Description of Novel Layar Terkembang}

Raden Wiriatmadja is a former regent of Banten, his wife has died, has two daughters named Tuti and Maria. Tuti is a school teacher HIS Arjuna in Petojo and Maria is a student of the last year of HBS Carpentier Alting Stichting. They live at the end of Gang Hauber crossing of Gang Cidengweg, Batavia (now Jakarta), the capital of Indonesia. Tuti is a figure of activist movement of women with goals and idealistic views, while Maria is a natural woman with joyfully fulfilling her teenage years and tends to direct her feelings rather than her intellect.

Tuti is twenty-seven years old and still a single woman. She once had a lover named Hambali and both of them were engaged. Tuti finally broke off the engagement because she did not want to tie his heart to men who only limited her movements in the public world and managed his life solely in the house. Tuti also wanted to be applied by a teacher named Soepomo, but she refused Soepomo's wishes. The reason for her refusal was that she would not accept marriage only as an escape from his loneliness or anxiety from his age of almost thirty, but she wanted to undergo a marriage because of the sincerity of love and logical consideration. On the other hand, Maria is a plain girl who has a lover named Yusuf. They establish a love naturally as the nature of God without requiring logical consideration.

At once time, Maria suffered from tuberculosis, first being treated at a hospital of Central Bugerlijk Zienken hais (CBZ) in Batavia, and then transferred to a rehabilitation center hospital in Rumah Sakit Pacet on the slopes of Mount Gede around the Sindanglaya area. Maria's illness worsened and by the time her death arrived, she requested that Tuti and Yusuf be willing to become husband and wife. Maria died at the age of 22 years. After the death of Maria, Tuti and Yusuf married based on a logical and sincere and eternal love of the afterlife,"Perhubungan sutera yang dianyam dalam keindahan alam pada pertukaran siang dan malam oleh seseorang yang dicintai, yang waktu itu berdiri di hadapan gerbang akhirat!” [8].

\subsection{Description of Novel Pride and Prejudice}

Mr. Bennet with his wife named Mrs. Bennet has five daughters named Jane Bennet, Elizabeth Bennet, Mary, Catherine, and Lydia. They live in Netherfield Park, England. Jane Bennet is the oldest daughter in the Bennet family, she is a girl who has a natural character, active, cheerful, agile, openly friends with men, and her feelings can be interpreted by men. Elizabeth Bennet is the second daughter, a woman who is educated, calm personality, intelligent, good at understanding the social conditions around her, sensitive to changing situations, and her views are full of logic. Mrs. Bennet is an ambitious mother, full of obsession with the marriages of her daughters to get married to men who are rich and of high social status.

Elizabeth Bennet hates a young man named $\mathrm{Mr}$. Fitzwilliam Darcy because she is considered arrogant and cunning. Elizabeth had refused the proposal of her father's brother, Mr. Collins because she considered her own uncle and she also had a chosen man named $\mathrm{Mr}$. Wickham. In the end, Elizabeth severed her relationship with Mr. Wickham because she knew that Mr. Wickham is an evil man who destroys the reputation of others by manipulating stories as if Mr. Fitzwilliam Darcy is a bad person. In another reality, Jane only had the experience of falling in love with a man named Mr. Charles Bingley. They naturally love with feelings without using a mindfully idealistic mind.

The love journey of Jane Bennet and Mr. Charles Bingley ended with a marriage that made Mrs. Bennet is very happy. Elizabeth Bennet with common sense realized that Mr. Fitzwilliam Darcy is actually a good and honest man, if he likes it, he shows his liking, and if he hates it, he expresses his displeasure. He openly tells the story of his family that the ugliness told by $\mathrm{Mr}$. Wickham is slander and engineering. Elizabeth Bennet finally sympathized with Fitzwilliam Darcy because of her honesty, openness, and responsibility. They married, lived happily, and settled in the Pemberly House, "Darcy, as well as Elizabeth, really loved them; and they were both ever sensible of the warmest gratitude towards the persons, who by bringing her into Derbyshire, had been the means of uniting them" [9].

\subsection{Tuti's view in the novel Layar Terkembang}

Tuti is an Indonesian women's movement activist who is active in managing women's organizations, including the chair's Jakarta branch of the women organization movement, Putri Sedar Organization. She even made a speech at the main congress of Putri Sedar Organization in Jakarta which presented the ideas of women's emancipation to release the bonds of male superiority over women. The Putri Sedar Organization aspires to women who are able to stand alone on equity with men in society and households. Tuti through the Putri Sedar Organization aspires that women in the 
social life of the community realize themselves equal to men. Women do not need to be pitied in marriage, must be independent, free to determine attitudes and standpoints. Tuti in one part of his speech said, "Demikianlah perempuan yang dicita-citakan oleh Puteri Sedar bukanlah perempuan yang berdiri dalam masyarakat sebagai hamba dan sahaya, tetapi sebagai manusia yang sejajar dengan laki-laki, yang tidak usah takut dan minta dikasihani” (2000: 40).

Tuti among the women's movement is known as a person who is good at giving speeches in conveying the spirit of renewal. She wants to make women aware of struggling to get the right and proper position in marriage and household. The submission of women in following traditions and customs will forever make women confined in their household routines, namely to serve their husbands and take care of their children. Women marrying and living a household life must be based on their willingness and desires. Women must realize that the purpose of their life is not just to be a wife as a male servant. Women must strive to obtain a more appropriate degree, appreciation, and position in domestic life.

Tuti discussed a lot with young men who were also movement activists like Yusuf about the position of women in the struggle of the Indonesian people. In each discussion, Tuti appeared as a figure of a woman who was full of goals, idealism, firm stance, and her words were stern. The Indonesian nation can be independent and advance in the future if women are given the freedom to develop their potential so they can struggle with men to build the nation. She also stressed that women in the life of the household must be given the freedom to empower themselves so that they are not always dependent on their husbands and not be humbled.

Tuti decided to terminate on his engagement with Hambali because their love was solely based on feelings of desire, not based on logic and common sense. Women must not dissolve in the cradle of feelings and weakness in welcoming the desire for marriage because men are easy to play with themselves. Women do not need to be married if they only give themselves up to attract men because forever she will be a male game. According to her mind, Hambali has not yet become her husband, but he has limited her activities in the social community. Tuti does not want to get married if the marriage only shackles women in empowering their potential in the midst of society. This was stated by Tuti in his view, "Perempuan tiada boleh memudahkan dirinya. Ia harus tahu di mana watas haknya terlanggar dan sampai ke mana ia harus dihormati dari pihak yang lain. Kalau tidak demikian, perempuan senantiasa akan menjadi permainan laki-laki. Dan daripada menjadi serupa itu, baginya baiklah ia tiada bersuami seumur hidupnya..." (2000: 40).
Tuti refused Soepomo's proposal to get marriage her because she did not want the marriage as an escape from his age of twenty-seven and was forced to accept the proposal. Actually Tuti does not reject marriage for women because marriage is a reality that cannot be denied as part of a woman's natural nature, but she refuses marriage which is solely for reasons of feeling not based on logical reasoning. Tuti finally married Yusuf because they found conformity in the view that husband and wife must love each other and earn a living together to realize mutual hope.

\subsection{Elizabeth's view in the novel Pride and Prejudice}

Elizabeth Bennet is an educated girl who comes from an established family. She always uses logic and common sense in dealing with problems as she shows when talking to Mr. Wickham, "Elizabeth allowed that he had given a very rational account of it, and they continued talking together with mutual satisfaction till supper put an end to cards; and gave the rest of the ladies their share of Mr. Wickham's attention" (1995: 57-58). Even though his mother named Mrs. Bennet encouraged her to accept the love of a rich and respectful man from the Bingley family, but she did not care about it and made her own decisions in a logical consideration. Similarly, the establishment of Elizabeth Bennet was not affected by the pressure of the laws of British inheritance. The law at that time stipulated that only boys could be heirs, while girls could not be inheritors of their parent's property. This provision does not allow her to obtain an inheritance because all his parents' property will belong to her uncle named $\mathrm{Mr}$. Collins. Elizabeth Bennet is firm in principle that women build a household based on love that is based on common sense, not because feelings or fears do not get wealth which ultimately destroys a woman's life.

Elizabeth Bennet has never positioned herself as a male rival; she only shows her existence as a woman who has social rights in family and society. She wants women to have the freedom to judge men before making a decision or making choices in marriage so that women are not demeaned by men. She showed her attitude in interacting with men like Mr. Charles Bingley, Mr. Fitzwilliam Darcy, Mr. Collins, and Mr. Wickham. Also, Elizabeth Bennet never hates men because for him man is a life-partner; she only hates arrogant and cunning man because he can play for a woman. Elizabeth Bennet believes that women do not need to position themselves as rivals of men in domestic life, but it is more appropriate to place themselves as partners or male partners in the social life of society.

Elizabeth Bennet has never opposed marriage in responding to her mother's wish that she be married to a rich and respectful man. She just does not want to accept marriage solely because of male interest in woman from physical aspects only. Male interest 
because of the beauty of a woman, then women receive male love because of wealth and social pride, so this is deception. This background of thought made Elizabeth experience a long process in finding the man who she was going to accompany to marry. Some men who had shown love to Elizabeth Bennet were Mr. Fitzwilliam Darcy, Mr. Collins, and Mr. Wickham. Elizabeth Bennet's principle is that women do not need to deny marriage as part of a woman's life journey, but women need to reject marriages that are done by deception.

Elizabeth Bennet initially hated Mr. Fitzwilliam Darcy because he was considered arrogant and disrespectful, she was then attracted to another man named Mr. Wickham after refusing Mr. Collins, but in the end Elizabeth Bennet received Mr. Fitzwilliam Darcy's love as a form of love that is real, honest, and sincere. In the view of Elizabeth Bennet, marriage must be built with common sense, not because it is based on abstract feelings of love. Elizabeth Bennet's love, which was built with Fitzwilliam Darcy, is love based on common sense, not because it induces feelings and pride, which sometimes destroys a woman's life. This Elizabeth Bennet's view is reflected in her words in the final parts of the Pride and Prejudice novel, "'I do, I do like him,' she replied, with tears in her eyes, 'I love him. Indeed he has no improper pride. He is perfectly amiable. You do not know what he really is; then pray do not pain me by speaking of him in such terms ", [9].

\subsection{The similarity views of Tuti and Elizabeth on marriage}

Tuti and Elizabeth Bennet have some similarities in fictional stories related to marriage and household. They are expressed as feminist goals, hopes, and ideals. The first thing to know is that Tuti and Elizabeth Bennet did not deny marriage to women because marriage is the natural nature of God as well as part of the life journey of women. At the end of the story, the two fictional characters finally married. Tuti is married to Yusuf, a movement activist who supports the Indonesian women's movement in obtaining their rights in various aspects of people's lives, especially education, social, and traditional. They were united in the spirit of nationalism to fight for the independence of the Indonesian nation which was still colonized as the fate of women who were enslaved by men in customs. Similarly, Elizabeth Bennet finally married Mr. Fitzwilliam Darcy, a man who is honest, sincere, open, and responsible. They are united based on their own will and desire with real love and are based on common sense.

Marriage rejected by Tuti and Elizabeth Bennet is a marriage that is based on feelings of abstract love, lulled by feelings, and loses common sense. Love like this is a weakness of women both outwardly and inwardly, so men are easy to play with themselves. This reason became the basis for Tuti in severing his engagement with Hambali and rejecting Soepomo's proposal. A similar reason was also made by Elizabeth Bennet in deciding to terminate her love with $\mathrm{Mr}$ Wickham and refuse Mr Collins. So, marriage is not the purpose of Tuti and Elizabeth's life, but marriage is part of the process of women's lives in the social life of society. Marriage is carried out based on logical considerations, not just indulging in feelings.

Tuti and Elizabeth Bennet shared the same view of the purpose of marriage for women that it was not just a wife and slave for men, but the marriage was intended as a space to develop the potential of a woman in the social life of the community. Tuti repeatedly advised her sister, Maria, who was considered to surrendering and her feelings for Yusuf to become his wife later as the only choice towards marriage. Similarly, Elizabeth Bennet was unhappy with the behaviour and thoughts of her sister, Jane Bannet, who stated that the purpose of her love was only married to live happily in the duties of Mr. Charles Bingley.

Tuti criticized the customs and traditions in society that placed women as slaves or servants for males in the household so that women had to make their husbands happy by giving up their lives just to take care of their husbands and children at home. Tuti rejected the view of a Javanese King named Mangkunegoro IV who stated that to be loved by a husband, the wife must adjust to her husband's wishes. According to Tuti, Mangkunegoro's statement made women bound and imprisoned in their homes, powerless to develop their intellectual potential in developing the nation and society. In another reality, Elizabeth Bennet also disagrees with the community's thinking that women must give themselves up to take care of their husbands and children so there is no need to think about things because their husbands fulfil all their needs. People try to have their daughters married by men who are rich and domiciled even though according to Elizabeth Bennet that these conditions make women lose their degree and self-esteem. Tuti and Elizabeth Bennet shared the view that women must obtain a more appropriate degree, appreciation, and position in domestic life.

Furthermore, Tuti and Elizabeth Bennet agreed in their view that they want the freedom to empower themselves in the lives of households so that they are not always dependent on their husbands and are not marginalized. They do not need to be pitied by men but they need independence and freedom to determine their attitudes or desires. Tuti agreed to choose Yusuf as her husband because she knew that Yusuf could respect herself and give her freedom in expressing views about the nation and society. Tuti felt that Yusuf was a man who could help herself to educate the community and improve tradition. The same thing happened to Elizabeth Bennet; she agreed to marry Mr. Fitzwilliam Darcy because she believes that Mr. Fitzwilliam Darcy 
is an honest man and respects her position as a wife. This choice of Tuti and Elizabeth Bennet reflects that they agreed to build a household based on love on the common sense, not feelings that ultimately destroyed a woman's life.

Tuti and Elizabeth Bennet both want to position themselves as partners or male partners in the social life of society, not as male rivals. Tuti never hated men as rivals, but she respected men in people's lives such as Hambali, Soepomo, Yusuf, and others. Tuti puts men as partners in building the nation and improving community traditions. The same thing was done by Elizabeth Bennet; she appreciated the presence of Mr. Charles Bingley, Mr. Fitzwilliam Darcy, Mr. Collins, Mr. Wickham, and others according to their profession and position. She recognizes the importance of men in people's lives because, without men, the continuity of humans will end. Finally, in both story of the novels against the background of the lives of Indonesian and English people, Tuti and Elizabeth Bennet agreed that husband and wife must love each other and earn a living together to realize mutual hope.

\section{CONCLUSION}

Tuti in the novel Layar Terkembang with a background in Indonesian society and Elizabeth Bennet in the novel Pride and Prejudice with a background in British society have some similarities in views on marriage and household. Based on the analysis in this article, it was concluded that there were nine similarities in the views of these two fictional characters, Tuti and Elizabeth Bennet.

1. Accepting marriage as the natural nature of God is also part of the life journey of women.

2. Do not want to order the cradle of her feelings and weaknesses in welcoming a marriage because men are easy to play with her.

3. Marriage must be based on one's own will and desire also is based on common sense, not based on abstract feelings of love.

4. The purpose of a woman to marry is not only becoming a wife as a male servant but also as a space to develop his potential in the social life of the community.

5. Obtaining better degrees, awards, and positions in household life.

6. Wanting freedom to empower themselves in domestic life so that women are not always dependent on their husbands are not demeaned, independent, free to determine attitudes and desires.

7. Building a household based on the love of common sense, not feelings that ultimately destroy a woman's life.

8. Positioning itself as a male partner in the social life of the community, not as a male rival.

9. Husbands and wives must love each other and make a living together in order to realize mutual hope.

\section{REFERENCES}

[1] Fromm, Erich. 2011. Cinta, Seksualitas, dan Matriarki. Terjemahan oleh Pipiet Maizier. Yogyakarta: Jalasutra.

[2] Smith, Emily Esfahani. 2014. The Power of Meaning: Crafting a Life That Matters. https: //www.theatlantic.com/health/archive/2014/06/happi ly-ever-after/372573/. Accessed on October 9, 2021 at 9.30 a.m

[3] Weijie, Chen, et al. 2010. How Female Characters Are Portrayed. https://www.divaportal.org/smash/get/ diva2:407214/fulltext01. Accessed on October 9, 2021 at 10.28 a.m.

[4] Wiyatmi. 2012. Kritik Sastra: teori dan aplikasinya dalam Sastra Indonesia. Yogyakarta: Ombak.

[5] Abbas. 2006. Perbandingan Idealisme Perempuan Indonesia dan Amerika 1920-1940 dan Refleksinya Dalam Novel Layar Terkembang dan My Mortal Enemy. Makassar: Era Media.

[6] Guerin, Wilfred L., et al. 1979. A Handbook of Critical Approaches To Literature. New York: Harper \& Row.

[7] Sugihastuti dan Itsna Hadi Saptiawan. 2010. Gender \& Inferioritas Perempuan. Yogyakarta: Pustaka Pelajar.

[8] Alisjahbana, St. Takdir. 2000. Layar Terkembang. Jakarta: Balai Pustaka.

[9] Austen, Jane. 1995. Pride and Prejudice. New York: Dover Publications. 